\title{
Sunglasses May Play a Role in Depression
}

\author{
Mahmut Alpayci ${ }^{1}$, Osman Ozdemir ${ }^{2}$, Seyfettin Erdem³ , Nazim Bozan ${ }^{4}$, Levent Yazmalar ${ }^{5}$
}

\section{ÖZET:}

Güneș gözlüg̃ünün depresyon gelişiminde bir rolü olabilir

Kış depresyonunun önerilen sebepleri arasında güneș ışı̃̃ının eksikliḡi, melatonin üretiminin baskılanamaması ve sonunda duyarlı kișilerde uyku/uyanıklık döngüsüyle ilișkili sirkadiyen ritimlerde bozulmayı içerir. Güneș ıșı̃̃ının ruh hali üzerindeki mevsimlik etkisi gibi, ruh hali günlük güneșli saatler ile de ilișkilidir. Güneș gözlükleri görünür ışı̃̃ın \%75-95'ini geçirmediḡinden, kullanıcılarda retinohipotalamik sistem yoluyla gözlerden beyine ulașan güneș ıșıg̃ının miktarı azalır. Güneș gözlüklerini takan insanlarda, kış depresyonu için önerilen sebeplerin ortaya çıkmasına benzer şekilde, güneș ışı̃̃ının antidepresan etkisi azalabilir ve sirkadiyen ritimler bozulabilir. Güneș ıșıg̃ının antidepresan etkisi oldug̃undan ve güneș gözlükleri güneș ıșıg̃ının maruziyetini azalttıg̃ından, güneș gözlüklerinin depresyonda bir rol oynayabileceg̃ini varsaydık.

Anahtar sözcükler: güneș gözlügü̈, depresyon, vitamin D

Journal of Mood Disorders 2012;2(2):80-3

\section{ABSTRACT:}

Sunglasses may play a role in depression

Proposed causes of winter depression include decrease in amount of sunlight, inability to suppress melatonin production, and finally disruption of circadian rhythms related to sleep/wake cycle in susceptible individuals. Like seasonal effect of sunlight on mood, the mood is also correlated with sunshine hours. The amount of sunlight reaching the brain from the eyes via retinohypothalamic tract is reduced in sunglass users, because sunglasses screen out $75 \%$ to $90 \%$ of visible light. In people wearing sunglasses, the antidepressant effect of sunlight may be reduced and circadian rhythms may be distorted, possibly leading to the emergence winter depression. Since the sunlight has antidepressant effect and since sunglasses reduce sunlight exposure, we hypothesized that sunglass use may play a role in depression.

Key words: depression, sunglasses; vitamin D

Journal of Mood Disorders 2012;2(2):80-3

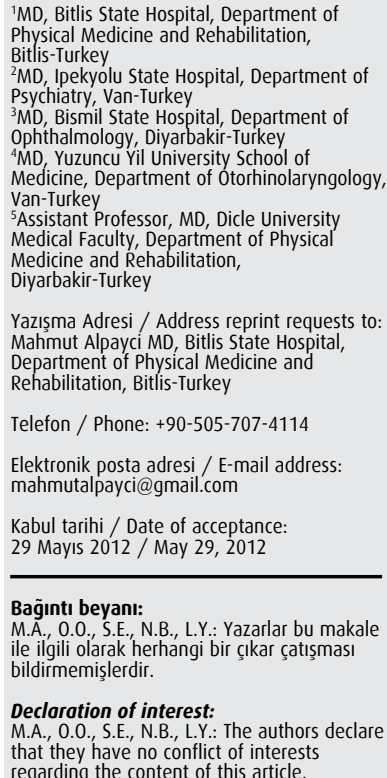

Telefon / Phone: +90-505-707-4114 Elektronik posta adresi / E-mail address: mahmutalpayci@gmail.com

Kabul tarihi / Date of acceptance 29 Mayıs 2012 / May 29, 2012

Bag̃ıntı beyan

M.A., 0.O., S.E., N.B., L.Y.: Yazarlar bu makale le ilgili olarak herhangi bir çıkar çatıșması dirmemișlerdir.

Declaration of interest: M.A., O.O., S.E., N.B., L.Y.: The authors declare that they have no conflict of interests

\section{BACKGROUND}

According to the American Optometric Association, to provide protection to the eyes sunglasses should filter out 99 to $100 \%$ of ultraviolet radiation rays and screen out $75 \%$ to $90 \%$ of visible light. Owing to protection from ultraviolet radiation, sunglasses are recommended to prevent ocular damage. Also, sunglasses are often used in the some conditions such as light sensitivity, travelling, etc. However, currently the use of sunglasses is very common as a fashion accessory, despite there is no medical indication.

Depression is a common mood disorder in the general population (1). Winter depression is characterised by recurrent episodes of depression in winter with spontaneous remission in summer (2). Photoperiodic hypothesis (PPH) assumes that longer nights/shorter days in winter leads winter depression by increasing duration of melatonin secretion (3). According to the phase shift hypothesis (PSH), winter depression is caused by decrease in light exposure during winter, which leads to disruption in circadian rhythms related to the sleep/ wake cycle $(2,3)$. The effectiveness of bright light therapy (BLT) for winter depression has been reported in randomized controlled studies (4).

In this article, we hypothesized that sunglasses may play a role in depression. To our knowledge, this is the first article that proposes a relationship between depression and sunglass use.

\section{Circadian Rhythms and Depression}

The regular circadian rhythm of night (dark) and day (light) regulates our metabolism (5). In humans, mood 
may exhibit changes across the 24 hour dark-light cycle (6). Beside seasonal changes occurring in the mood (e.g. winter depression), it has been shown that the mood may be correlated with daily hours of sunshine (3). Also, recent studies have revealed that depression severity may be correlated with the degree of circadian misalignment $(2,3)$. For healthy metabolism and psychological activity, a harmony between the environmental and endogenous circadian rhythms is required. Disruptions to circadian rhythms have been found among patients with major depression (5).

\section{Light Therapy and Depression}

Light exposure can affect serum melatonin levels and circadian rhythms. Nighttime stimulates melatonin secretion while daylight suppresses it (7). Also, it has been demonsrated that light is a factor in the timing of the circadian clock. Light activates retinal ganglion cells which in turn excite the hypothalamic suprachiasmatic nucleus (SCN), the biological clock of the brain, via the retinohypothalamic tract (8). Exposure to bright light in the morning hours can suppress the production of the hormone melatonin and regulate circadian rhythms in depression patients $(4,5)$. Moreover, two new clinical trials demonstrated that channeling bright light via ear canal into brain's photosensitive areas was effective in preventing and treating winter depression (9).

\section{Melatonin and Depression}

Melatonin is secreted primarily by the pineal gland in a specific circadian pattern in accordance with the light/ dark cycle and the seasonal cycle. Abnormal serum melatonin levels have been reported in patients with winter depression (7). Evidence suggests that melatonin supplements can decrease transmeridian travel (jetlag) symptoms in people with disrupted circadian rhythms (5). Also, melatonin may improve sleep patterns and reduce the symptoms in patients with depression. However, melatonin administration during the day leads to worsening of depressive symptoms, indicating melatonin does not have an inherent antidepressant action (5). Therefore, given melatonin in the evening can improve the mood in winter depression by synchronizing between circadian rhythms related to the sleep/wake cycle (5).

\section{Vitamin D and Depression}

It has been suggested that vitamin $\mathrm{D}$ deficiency may play a role in depression (10). Because exposure to sunlight accounts for over $90 \%$ of the vitamin D requirement for most individuals (11), inadequate sunlight exposure may cause vitamin D deficiency and also restrict the antidepressant effect of light. Therefore, the comorbidity of major depression and vitamin D deficiency may be due to inadequate sunlight exposure. Nevertheless, vitamin D deficiency can cause secondary depression via its role in so many different chronic diseases (e.g. bone disease, autoimmune disorders, cancer, cardiovascular disease, and mood disorders) $(12,13)$. Depression secondary to these disorders might be accompanied by deficiency of vitamin D. Improvement in depressive symptoms with vitamin D supplement (14) might be related to recovery from the chronic diseases linked to vitamin D deficiency. So, the relationship between vitamin $\mathrm{D}$ and depression may be more complex than just low sunlight exposure.

\section{HYPOTHESIS}

Normal sunglasses reduce the exposure of the eyes to sunlight and create a dim environment. Thus, effect of sunlight is reduced on the eyes and also on the brain of people who wear sunglasses. In this condition, some alterations in the serum levels of melatonin and serotonin may be possible, and circadian rhythms disruption may occur, similar to the emergence of proposed causes for winter depression. Since sunglasses reduce sunlight exposure, we hypothesized that sunglasses may play a role in depression, taking account of the etiopathological mechanisms of winter depression and antidepressant effect of sunlight.

\section{DISCUSSION}

Proposed hypotheses (PPH and PSH), which explain the etiopathological mechanisms of winter depression, accept that some changes emerging during the winter are causes of this condition. These changes include the increased melatonin secretion, decreased exposure to sunlight as a consequence of shorter days and longer nights, and as a result the disruption of circadian rhythms 
related to sleep-wake cycle $(4,5)$. Bright light therapy (BLT), which aims to restore these pathological changes, can improve the depressive symptoms (7). This effect of BLT may occur through the suppression of melatonin (5).

Patients with winter depression have abnormal melatonin serum levels (high melatonin levels during daytime, prolonged nocturnal melatonin secretion in winter, and a phase delay of melatonin release) (7). Also, light exposure has the potential to change the circadian rhythms and the melatonin secretion (7). However, ordinary room light levels are not enough to melatonin suppression (2). For this reason, melatonin level cannot be suppressed in the morning and dim light melatonin onset (DLMO) may occur. Similarly, because of exposure to light is reduced, melatonin suppression may disappear, and DLMO may arise in sunglass users.

Due to the increase of melatonin, serotonin levels may fall, because melatonin is synthesized from its precursor serotonin before it is rapidly distributed within the body (7). It is known that low levels of serotonin in the brain may lead to depression. Also, studies show that there is a relationship between serotonin and bright light (4). Melatonin levels during daytime may be higher in sunglass users like in patients with winter depression. Since bright light suppresses melatonin levels (5), sunglasses can block suppressing effect of bright light on melatonin secretion, and result in reduced serotonin levels.

There is the antidepressant effect of bright light, so that, sunglasses that reduce light exposure may play a role in depression. The amount of sunlight that reaching to the brain from the eyes via retinohypothalamic tract is reduced in sunglass users, because sunglasses screen out $75 \%$ to $90 \%$ of visible light. In people wearing sunglasses, the antidepressant effect of sunlight may be reduced and circadian rhythms may be distorted, similarly to the emergence of proposed causes for winter depression.

The human circadian pacemaker or 'clock' is located in the suprachiasmatic nucleus of the anterior hypothalamus (5). Sunglasses can affect the hypothalamus via the retinohypothalamic tract by reducing light exposure to eyes. Thus, in sunglasses wearers the circadian rhythms may be affected. Disruptions of circadian rhythms have been found among patients with major depression (5).

Similar to patients with winter depression, seasonal mood changes result in the circadian rhythm disturbance and for the same reason it is possible in at least daily mood swings can be affected by sunglass use. Some studies showing correlation between mood and daily sunshine hours as well as antidepressant effect of BLT support this view (3).

Bright light, which can supress melatonin, improves the circadian rhythm disturbances and as a result depressive symptoms may be relieved. Whereas, the low light exposure and dim environment occurring in people wearing sunglasses outdoors may not be enough to suppress melatonin and the risk of circadian rhythm disruption may increase especially in more vulnerable people. In a case report it has been reported that dark sunglasses block the antidepressant effects of bright light (15).

On the other hand, the emergence of depression or increase in disease severity may be related to duration of daytime sunglass use, because depression severity is correlated with the degree of circadian misalignment $(2,3)$ and mood is correlated with daily hours of sunshine (3). Also, melatonin administration during the day leads to worsening of depressive symptoms (5). In other words it is possible that the longer the use of sunglasses is the greater the risk of depression.

\section{CONCLUSION}

Today, sunglasses are used around the world as a fashion accessory without any medical indication. In this article, we hypothesized that sunglasses may play a critical role in depression. We wanted to alert sunglass users about the risk of depression by taking account the above mentioned etiopathological mechanisms of winter depression and antidepressant effect of sunlight. Nevertheless, this hypothesis needs to be tested. If the hypothesis would be confirmed, sunglass use will be considered as a risk factor for depression.

\section{TESTING THE HYPOTHESIS}

We suggest the following approaches to test some aspects of the hypothesis:

1. Retrospective: to compare the patients with depression and healthy control group, in terms of the use of sunglasses. 2. Prospective: to compare the subjects using and not using sunglasses, in terms of depression severity.

3. To measure and compare serum melatonin and serotonin levels with and without sunglass use during daytime. 


\section{References:}

1. Annagür BB, Savaş HA. Comorbid disorders in depression, depression as comorbidity: a review of studies from Turkey. JMOOD. 2011; 1: 87-94.

2. Lewy AJ, Emens JS, Songer JB, Sims N, Laurie AL, Fiala SC, But AL. Winter Depression: Integrating mood, circadian rhythms, and the sleep/wake and light/dark cycles into a bio-psycho-socialenvironmental model. Sleep Med Clin. 2009; 4: 285-99.

3. Roecklein KA, Rohan KJ, Postolache TT. Is seasonal affective disorder a bipolar variant? Curr Psychiatr. 2010; 9: 42-54.

4. Virk G, Reeves G, Rosenthal NE, Sher L, Postolache TT. Short exposure to light treatment improves depression scores in patients with seasonal affective disorder: A brief report. Int J Disabil Hum Dev. 2009; 8: 283-86.

5. Boyce P, Barriball E. Circadian rhythms and depression. Aust Fam Physician. 2010; 39: 307-10.

6. Germain A, Kupfer DJ. Circadian rhythm disturbances in depression. Hum Psychopharmacol. 2008; 23: 571-81.

7. Pail G, Huf W, Pjrek E, Winkler D, Willeit M, Praschak-Rieder N, Kasper S. Bright-light therapy in the treatment of mood disorders. Neuropsychobiology. 2011; 64: 152-62.

8. Most EI, Scheltens P, Van Someren EJ. Prevention of depression and sleep disturbances in elderly with memory-problems by activation of the biological clock with light--a randomized clinical trial. Trials. 2010; 11:19.
9. Lauren Paxman. Shining a Light in Your Ear 'Can Brighten Your Mood in Winter' http://lewrockwell.com/spl3/brighten-wintermood.html. 04.02.2012.

10. Berk M, Sanders KM, Pasco JA, Jacka FN, Williams LJ, Hayles AL, Dodd S. Vitamin D deficiency may play a role in depression. Med Hypotheses. 2007; 69: 1316-9.

11. Penckofer S, Kouba J, Byrn M, Estwing Ferrans C. Vitamin D and depression: where is all the sunshine? Issues Ment Health Nurs. 2010; 31: 385-93

12. Yuen AW, Jablonski NG. Vitamin D: in the evolution of human skin colour. Med Hypotheses. 2010; 74: 39-44.

13. Murphy PK, Wagner CL. Vitamin D and mood disorders among women: an integrative review. J Midwifery Womens Health. 2008; 53: 440-6.

14. Jorde R, Sneve M, Figenschau Y, Svartberg J, Waterloo K. Effects of vitamin D supplementation on symptoms of depression in overweight and obese subjects: randomized double blind trial. J Intern Med. 2008; 264: 599-609.

15. Moscovici L. Bright light therapy for seasonal affective disorder in Israel (latitude 32.6 degrees $\mathrm{N}$ ): a single case placebo-controlled study. Acta Psychiatr Scand. 2006; 114: 216-8. 